\title{
A.A. Нафеeв
}

\section{РИСК ПРОФЕССИОНАЛЬНОГО ЗАРАЖЕНИЯ ЗООНОЗАМИ}

ФБУЗ «Центр гигиены и эпидемиологии в Ульяновской области», 432005, Ульяновск, ул. Пушкарева, 5; «Ульяновский государственный университет», 432017, Ульяновск, ул. Льва Толстого, 42

\begin{abstract}
В данной работе представлен материал о риске инфицирования работников животноводства возбудителями коксиеллеза (Ку-лихорадка), лептоспирозов и орнитоза. Показаны трудности современного этапа в организации и проведении их диагностики и эпидемиологического надзора. Представленный материал наглядно демонстрирует, что присутствие на разного вида ветеринарных объектах не выявленных инфицированных (больных) животных и птии при несоблюдении мер защиты может способствовать инфииированию сотрудников, а в дальнейшем и развитию заболеваний. Применение современных методов лабораторной диагностики с учетом профессионального фактора и природы инфекиионных заболеваний (зоонозов) играет ведущую роль в выявлении таких случаев.

К л юч е в ы е с л о в а : Ку-лихорадка, лептоспирозы, орнитоз, серологические методы диагностики
\end{abstract}

A. A. Nafeev

RISK OF PROFESSIONAL INFECTION WITH ZOONOSES

Center of Hygiene and Epidemiology in the Ulyanovsk region, Pushkareva Str., 5 Ulyanovsk, Russian Federation, 432005; Ulyanovsky State University, 42, Leo Tolstoy Str., Ulyanovsk, Russian Federation, 432970

In this paper there is presented a material about the risk of infection of livestock workers with pathogens of Coxiellosis $(Q$ fever), leptospirosis and pet shop workers - with psittacosis. The use of modern methods of laboratory diagnosis with taking into account the professional factors and the nature of infectious diseases (zoonoses) has played a leading role in identifying such cases.

Key words: Qfever, leptospirosis, psittacosis, serological diagnostic methods

В настоящее время в связи с социально-экономическими изменениями, возникшими в 90-е годы $\mathrm{XX}$ века в сельском хозяйстве (изменение формы ведения животноводства, системы ветеринарного контроля), актуальной задачей многих служб и ведомств является выяснение истинной эпизоотической ситуации по отдельным зоонозным инфекциям среди населения (Ку-лихорадка, лептоспирозы, орнитоз) с целью поддержания на территории действенного эпизоото-эпидемиологического надзора. Некоторые из этих инфекций считаются более распространенными, но их частоту трудно определить, поскольку большинство инфекций не имеют ярких клинических проявлений, и болезнь может протекать в легкой (субклинической) форме, что создает трудности при диагностике из-за неспецифических симптомов. Одним из таких заболеваний является орнитоз, который в течение длительного времени рассматривался как профессиональная патология. Отсутствие частой регистрации объясняется трудностью диагностики орнитоза (пситаккоза) из-за полиморфизма клинических проявлений хотя известно, что орнитоз достаточно широко распространенная инфекционная патология. На его долю может приходить до 10\% от общего числа всех регистрируемых пневмоний [1].

Диагностика спорадических случаев пситаккоза представляет большие трудности, так как недооце-

Для корреспонденции: Нафеев Александр Анатольевич, зав. отд-нием особоо опасных инфекций ЦГиЭ в Ульяновской обл.; доктор мед. наук, проф. УГУ мед. фак. каф. инфекционных и кожно-венерических болезней, e-mail: nafeev@mail.ru нивается роль эпидемиологического фактора в диагностике пситаккоза. Она существенно облегчается при выяснении характерных эпидемиологических данных: профессиональная деятельность - работа на птицеводческих комплексах, в последние годы во множестве появились зоомагазины или отделы в торговых центрах, реализующие декоративную птицу; бытовые контакты с птицами (попугаями, голубями, утками, чайками и др.).

Учитывая вышеизложенное, необходимо было, используя скрининговые иммунологические исследования, оценить характер эпидемического процесса лептоспироза и коксиеллеза (лептоспироз в области был злободневной проблемой в 70-80-е годы, когда практически ежегодно имели место водные вспышки, а по Ку-лихорадке ничего не известно с конца 60-х годов) среди профессиональных групп населения в настоящее время. Кроме того, на примере 2 случаев орнитоза показать вероятность появления острых случаев инфекции.

Распространенность зоонозных инфекций в большинстве стран уменьшается благодаря активным программам контроля здоровья животных. Несмотря на это работники сельского хозяйства и люди, чьи профессии связаны с животными или сырьем животного происхождения, остаются подверженными высокому риску многих заболеваний.

\section{Материалы и методики}

Материалом для исследования служили пробы сыворотки практически здоровых людей, составляющих отдельные профессиональные группы (вете- 
ринарные специалисты, работники животноводства и предприятий по переработке сырья животного происхождения), отобранных по результатам анализа амбулаторных карт и историй болезни в возрасте от 30 до 70 лет, а также истории болезни 2 больных орнитозом. В реакциях микроагглютинации и лизиса (РМАл) и иммунофлюоресцентных антител (ИФА) исследовано более 400 сывороток работников мясокомбинатов и работников животноводства (1994-1995 гг.) на лептоспироз и 538 сывороток работников животноводства (2006-2007 гг.) на Кулихорадку.

\section{Результаты исследования}

Острая Ку-лихорадка - инфекция, которая после инкубационного периода (от 4 до 40 дней) напоминает похожую на грипп болезнь, в дальнейшем приобретающая признаки микоплазменной пневмонии. Острая стадия болезни продолжается приблизительно две недели, но может растянуться и до 9 нед. Наиболее сложными в диагностическом плане являются хронические формы заболевания (преимущественно эндокардит и гепатит), которые могут развиваться в течение 20 лет после острой стадии. Разнообразие клинических проявлений и отсутствие патогномоничных признаков заболевания вынуждает использовать для постановки достоверного диагноза комплекс приемов, включающих эпизоотологические, эпидемиологические данные, клинические проявления и обязательно результаты серологических исследований, направленных на обнаружение антител к коксиеллам Бернета. Острый коксиеллез всегда характеризуется более высоким (на несколько порядков) уровнем антител к антигенам II фазы. У большинства больных антитела появляются на 2-3-й неделе болезни и сохраняются до 11-23 лет. Антитела к антигенам фазы І выявляются лишь спустя 30 дней от начала болезни и сохраняются не более 2-3 лет [2]. Положительную реакцию только с антигеном фазы II большинство исследователей рассматривает как свидетельство развития острого патологического процесса. Обнаружение антител к обоим фазовым вариантам коксиелл дает основание говорить либо о хронической форме болезни, либо об анамнестической реакции на давно перенесенную инфекцию. Высокая концентрация антител к фазе I свидетельствует о хронической форме инфекции и характерна для больных с подострым или хроническим коксиеллезным эндокардитом [3]. Постановка диагноза коксиеллеза в остром периоде затруднительна по причине незначительного количества случаев с тяжелой формой клинического течения заболевания. В Северо-Западном регионе РФ от 1,5 до 3,3\% доноров, обследованных в 80-х и 90-х годах прошлого века имели в сыворотках крови антитела к C. burnetii [3], в Ульяновской обл. - 3,2-4,5\%. Для нашего региона вопросы совершенствования диагностических подходов к постановке диагноза Ку-лихорадки стоят остро в связи с выявлением при проведении серологического (иммунологического) скрининга иммуноглобулинов класса G. Начало регистрации лихорадки Ку в Ульяновской области по архивным материалам датируется 1958 г. (1 случай), в последующем заболеваемость имела место: 1965 г. (4), 1966 г. (2), 1968 г. (2); с 1963 по 2001 г. диагностика данной инфекции не проводилась. Начиная с 2002 по 2011 г. диагноз Ку-лихорадки выставлялся в 50 случаях: 2002 г. (1), 2003 г. (5), 2004 г. (12), 2005 г. ${ }^{1}$, 2006 г. (6), 2007 г. (7), 2008 г. (1), в 2009 г. случаи заболеваний не регистрировались, 2010 г. (9), 2011 г. (9). Особенно важным при исследовании послужил период с 2004 по 2011 г., где из 44 случаев заболеваний коксиеллеза только 6 имели острую форму заболевания (4 случая завоза туристами из Египта и Кипра, 2 случая среди местного населения). Источник во всех 6 случаях не установлен. Остальные (86,4\%) случаи были выявлены ретроспективно у работников изучаемой группы (титры антител в реакции ИФА составили 1:400 и 1:800, с подтверждением в реакции непрямой иммунофлюоресценции). Результаты ретроспективного эпидемиологического анализа (протестировано в период 2006-2007 гг. 538 образцов сывороток, антитела к I фазе обнаружены в 20 из них, что составило 3,7\%) подтверждают имевшее место в прошлом инфицирование коксиеллами Бернета работников животноводства и определяют необходимость проведения углубленного эпидемиологического обследования работающих профессиональных групп населения в сравнении с контрольной группой (в период 1970-2000 гг.).

Анализ многолетней динамики заболеваемости лептоспирозом в РФ за исследуемый период (с 1950 по 2011 г.) указывает на неравномерность развития эпидемического процесса. Заболеваемость лептоспирозом на территории России в течение первых 17 лет (1950-1966 гг.) была высокой, в отдельные годы поставляла до 7,0 на 100 тыс. населения (в Ульяновской обл. в 1964 г. до 7,9). Подъем заболеваемости лептоспирозом в эти годы был обусловлен развитием животноводства и строительством животноводческих (в частности, свиноводческих) комплексов. В результате индустриализации животноводства имела место высокая концентрация животных на ограниченных территориях, что приводило к концентрации источников инфекции в хозяйствах и росту заболеваемости, связанной с профессиональной деятельностью. Начиная с 1967 г. уровень заболеваемости лептоспирозом в России стал снижаться. Интенсивные показатели были в пределах от 0,3 до 0,7 на 100 тыс. населения. В Ульяновской обл. такая динамика отмечается с 1965 г. (за исключением 1974 г., когда имели место две крупные вспышки, что отразилось на показателях 13,1 на 100 тыс.). Начало 80-х годов прошлого века сопровождалось незначительным подъемом забо-

\footnotetext{
Заболеваемость не регистрировалась
} 
леваемости лептоспирозом в РФ с колебаниями от 0,47 до 0,85 на 100 тыс. населения. Заболеваемость в этот период была обусловлена профессиональной деятельностью в животноводстве (в Ульяновской обл. этот период удлинился до 1999 г. - 4,1 на 100 тыс.), включая предприятия по переработке сырья животного происхождения. Третий подъем заболеваемости лептоспирозом в РФ начался в 1988 г. (с коэффициентом роста 2,0 по сравнению с 1987 г.), что объясняется урбанизацией антропоургических очагов, при этом отмечалась резко возросшая роль собак на территориях городов, и возникновением эпизоотий лептоспироза среди этих животных. Этот процесс привел и к изменению в микробиоценозе очагов - доминирование сероварианта Canicola с вытеснением других серовариантов возбудителя. Современный период характеризуется снижением инцидентности лептоспироза в России (показатель заболеваемости в целом по России колеблется в пределах от 0,8 до 1,6 на 100 тыс.), что находит подтверждение и в Ульяновской обл. (2011 г. 0,14$)$.

При обследовании на 13 серогрупп лептоспир выявлено 26 (6,0\%) человек с антителами, из них диагностический титр (1:100) имели 11 (42,3\%) человек. При проведении через 3 мес у этих лиц повторного обследования у 8 было установлено нарастание титра антител, что позволило диагностировать субклинические безжелтушные формы лептоспироза. При сравнении серогрупп у людей и животных установлено их совпадение: преобладали L. Pomona (41,5\%), L. Icterohaemorrhagiae (15,1\%), L. Canicola $(13,2 \%)$. Обращает на себя внимание частота выявления L. Canicola, что объясняется наличием на ветеринарных объектах сторожевых и безнадзорных собак, которые в плановом порядке ветеринарной службы специфической профилактикой не охватываются [4].

В апреле 2011 г. в инфекционный стационар МУЗ Центральная городская клиническая больница с интервалом в 2 дня поступили две женщины с лихорадкой и жалобами на слабость и поражение органов дыхания (в одном случае с редким сухим кашлем, в другом с кашлем с трудноотделяемой мокротой). Из эпиданамнеза установлено, что обе больные работают в зоомагазинах (стаж работы 6 и 8 мес), принадлежащих одному частному владельцу, и около месяца назад они отмечали наличие больных попугаев, находящихся на реализации в клетках. При обследовании женщин установлено: состояние средней тяжести, при аускультации - в одном случае сухие хрипы слева, в другом - жесткое дыхание в нижних отделах, больше слева, выслушиваются рассеянные сухие хрипы. Рентгенография органов грудной клетки: в случае с редким сухим кашлем - без патологии, в случае с кашлем с трудноотделяемой мокротой левосторонняя пневмония. Изменений в других органах и системах не выявлено.

При проведении эпидемиолого-эпизоотологического исследования очагов орнитоза, связанных с зоомагазинами, установлено, что отсутствуют сопроводительные документы на птиц, характеризующие территориальное и видовое происхождение, ветеринарно-санитарное состояние груза, эпизоотическое состояние места его выхода, позволяющие идентифицировать животных.

Следует учесть, что эпидемиологическое обследование очага проводится с учетом эпизоотологических данных ветеринарной службы (от их объективной и достоверной информации зависит итоговый результат - выявление инфицированных (больных) работников и их лечение, предупреждение повторных случаев), а при возникновении нескольких случаев - совместно с ее работниками.

Таким образом, представленный материал наглядно демонстрирует, что присутствие на разного вида ветеринарных объектах не выявленных инфицированных (больных) животных и птиц при несоблюдении (отсутствии) мер защиты может способствовать инфицированию сотрудников, а в дальнейшем и развитию заболеваний. Применение современных методов лабораторной диагностики с учетом профессионального фактора и природы инфекционных заболеваний (зоонозов) играет ведущую роль в выявлении таких случаев.

\section{Л И ТЕРАТ У РА}

1. Черкасский Б.Л. Особо опасные инфекции. М.: Медицина; 1996.

2. Лобан К.М., Лобзин Ю.В., Лукин Е.П. Риккетсиозы человека: руководство для врачей. М.; СПб.; 2002: 393-474.

3. Камара А.М.-Б, Буаро М.И., Трофимов Н.М., Рытик П.Г., Терехович Т.И. Медицинские новости. 2009; 5: 8-11.

4. Нафеев А.А., Меркулов А.В., Пашков В.Ф., Жадаева Л.И. Лептоспирозы как профессиональные заболевания. Казанский медицинский журнал. 2001; 82 (1): 54-6.

\section{REFERENCES}

1. Cherkasky B.L. Particularly dangerous infections. Moscow: Medicine; 1996 (in Russian).

2. Loban K.M., Lobzin Yu.V., Lukin E.P. Rickettsiosis people: Hands-on for physicians. M.; SPb.; 2002: 393-474 (in Russian).

3. Camara A.M.-B., Bouar M.I., Trofimov N.M., Rytik P.G., Terehovich T.I. Med. news. 2009; 15: 8-11 (in Russian).

4. Nafeev A.A., Merkulov A.V., Pashkov V.F., Zhadaeva L.I. Kasane. med. zhurn., 2001; 82 (1): 54-6 (in Russian). 